\title{
SUPERVISI AKADEMIK UNTUK MENINGKATKAN KOMPETENSI PROFESIONAL GURU PENJASOR DALAM MENERAPKAN METODE DEMOSTRASI PADA LATIHAN KEBUGARAN JASMANI
}

\author{
Anwar \\ Kepala SDN Sampangagung I Kutorejo, Mojokerto \\ Email: pakanwar5@gmail.com
}

Tersedia Online di

http://www.jurnal.unublitar.ac.id/ index.php/briliant

\section{Sejarah Artikel}

Diterima pada 2 Januari 2017

Disetuji pada 20 Januari 2017

Dipublikasikan pada 1 Februari

2017 Hal. 7 - 11

\section{Kata Kunci:}

supervisi akademik, kompetensi guru, metode demostrasi,

kebugaran jasmani

\begin{abstract}
Abstrack: Tujuan dari penelitian ini adalah (a) mendeskripsikan peningkatan kemampuan guru dalam mengelola pembelajaran, (b) mendeskripsikan bagaimana peningkatan hasil belajar latihan dasar kebugaran dalam pendidikan jasmani pada siswa setelah diterapkannya metode domonstrasi, (c) mengetahui motivasi belajar latihan dasar kebugaran dalam pendidikan jasmani setelah diterapkannya metode domonstrasi. Jenis penelitian ini menggunakan penelitian tindakan (action research) sebanyak dua putaran Sasaran. Subyek penelitian ini adalah guru penjasor dan Siswa Kelas V SD Sampangagung 2. Dari hasil analisis didapat bahwa supervisi Akademik dengan penerapan metode domonstrasi mempunyai pengaruh positif, yaitu dapat meningkatkan kompetensi guru dan hasil belajar siswa.
\end{abstract}

Pendidikan Jasmani merupakan media untuk mendorong perkembangan keterampilan motorik, kemampuan fisik, pengetahuan, penalaran, penghayatan nilai (sikap-mental-emosional-spiritual-sosial), dan pembiasaan pola hidup sehat yang bermuara untuk merangsang pertumbuhan serta perkembangan yang seimbang. Dengan Pendidikan Jasmani siswa akan memperoleh berbagai ungkapan yang erat kaitannya dengan kesan pribadi yang menyenangkan serta berbagai ungkapan yang kreatif, inovatif, terampil, memiliki kebugaran jasmani, kebiasaan hidup sehat dan memiliki pengetahuan serta pemahaman terhadap gerak manusia.

Kebugaran jasmani merupakan segenap kemampuan seseorang untuk melakukan tugasnya sehari-hari tanpa mengalami kelelahan yang berarti. Selain itu, mereka masih mempunyai cadangan energi untuk menikmati waktu senggangnya serta untuk keperluan yang sifatnya mendadak. Kebugaran jasmani memiliki unsur-unsur yang meliputi : kekuatan otot, daya tahan paru dan jantung, serta kecepatan. Untuk mendapatkan kebugaran jasmani bagi tubuh kita. perlu dilakukan latihan yang teratur dan terukur. Berikut ini beberapa bentuk latihan untuk meningkatan kebugaran jasmani.

Dalam proses pembelajaran Pendidikan Jasmani kami sebagai seorang guru diharapkan mengajarkan berbagai keterampilan gerak dasar, teknik dan strategi permainan dan olahraga, internalisasi nilai-nilai (sportifitas, jujur, 
kerjasama, dan lain-lain) serta pembiasaan pola hidup sehat. Pelaksanaannya bukan melalui pengajaran konvensional di dalam kelas yang bersifat kajian teoritis, namun melibatkan unsur fisik, mental, intelektual, emosi dan sosial. Aktivitas yang diberikan dalam pengajaran harus mendapatkan sentuhan didaktikmetodik, sehingga aktivitas yang dilakukan dapat mencapai tujuan pengajaran, namun kenyataannya lain dari apa yang diharapkan.

Berdasarkan refleksi awal yang kami lakukan pada 4 Agustus 2016 awal semester terhadap guru penjasor kelas $\mathrm{V}$ tentang latihan dasar kebugaran jasmani menunjukkan hasil sebagai berikut: (1) Guru dalam pembelajaran latihan dasar kebugaran belum menyesuaikan antara materi dan usia siswa. (2) Guru kurang memperhatikan antara kemampuan siswa dengan cara penyampaian materi, sehingga siswa mengalami kesulitan dalam melakukan gerakan-gerakan kebugaran jasmani. (3) Kurangnya antusias siswa pada saat pembelajaran berlangsung bahkan ada beberapa siswa yang cenderung tidak aktif, hanya sebagian siswa yang mendengarkan dan duduk-duduk saja pada saat latihan kebugaran jasmani. (4) Guru kurang memotivasi siswa supaya bertanya apa yang belum dipahami. (5) Aktivitas belajar siswa rendah dan hasil belajar belum memenuhi KKM.

Berdasarkan uaraian di atas, maka peneliti berketetapan bahwa Kompetensi Dasar : Siswa dapat melakukan teknik kebugaran kelas V semester 1 perlu mendapatkan perbaikan pembelajaran. Perbaikan pembelajaran peneliti lakukan Dengan Supervisi Akademik. Glickman (1981), mendefinisikan supervisi akademik adalah serangkaian kegiatan untuk membantu guru mengembangkan kemampuannya mengelola proses pembelajaran demi pencapaian tujuan pembelajaran. Supervisi akademik merupakan upaya membantu guru-guru mengembangkan kemampuannya mencapai tujuan pembelajaran.

Supervisi pada dasarnya diarahkan pada dua aspek, yakni: supervisi akademis, dan supervisi manajerial. Supervisi akademis menitikberatkan pada pengamatan pengawas terhadap kegiatan akademis, berupa pembelajaran baik di dalam maupun di luar kelas. Supervisi manajerial menitik beratkan pada pengamatan pada aspek-aspek pengelolaan dan administrasi sekolah yang berfungsi sebagai pendukung (supporting) terlaksananya pembelajaran.

\section{METODE}

\section{Rancangan Penlitian}

Penelitian ini merupakan penelitian tindakan (action research) karena penelitian dilakukan untuk memecahkan masalah pembelajaran di kelas. Dalam penelitian tindakan ini menggunakan bentuk penelitian kolaboratif dengan guru mata diklat sebagai praktikan sedangkan peneliti bertindak sebagai supervisi sekaligus pengamat, penanggung jawab penuh penelitian tindakan adalah pengamat (peneliti).

PTS terdiri atas empat tahap, yaitu planning (Rencana), action (tindakan), observasi (pengamatan) dan reflection (refleksi). Rancangan/rencana awal, sebelum mengadakan penelitian peneliti menyusun rumusan masalah, tujuan dan membuat rencana tindakan, termasuk di dalamnya instrument penelitian dan perangkat pembelajaran. Kegiatan dan pengamatan, meliputi tindakan yang 
dilakukan oleh peneliti sebagai upaya membangun pemahaman konsep siswa serta mengamati hasil atau dampak dari ditetapkannya supervisi akademik. Refleksi, peneliti mengkaji melihat dan mempertimbangkan hasil atau dampak dari tindakan yang dilakukan berdasarkan lembar pengamatan yang diisi oleh pengamat Rancangan/rencana yang direvisi, berdasarkan hasil refleksi dari pengamat membuat rancangan untuk dilaksanakan pada siklus berikutnya

\section{Tempat, waktu dan Subjek Penelitian}

Penelitian ini bertempat di SDN Sampangagung-1 Kecamatan Kutorejo Kab Mojokerto. Penelitian ini dilaksanakan selam 4 bulan yaitu pada bulan Agustus - Nopember 2016. Subjek penelitian adalah Guru Penjasor serta siswasiswi kelas V yang terdiri dari siswa laki-laki 8 anak, sedangkan perempuan 12 anak, dengan jumlah keseluruhan 20 siswa tahun pelajaran 2016-2017.

\section{Instrumen Penelitian}

Instrument yang digunakan dalam penelitian ini terdiri dari: (1) Silabus, (2) Rencana Pembelajaran (RP), (3) Lembar Observasi Kegiatan Belajar Mengajar terdiri Lembar untuk mengamati kemampuan guru, (4) Lembar untuk mengamati aktivitas siswa. (5) Lembar Tes praktek, Bentuk soal yang diberikan adalah pilihan ganda (objektif). Sebelumnya soal-soal berjumlah 10 soal pilihan ganda dan 5 soal esay digunakan pada subyek penelitian, peneliti mengadakan analisis butir soal tes yang telah diuji validitas dan reliabilitas pada tiap soal.

\section{Metode Pengumpulan Data}

Data-data yang diperlukan dalam penelitian ini diperoleh melalui observasi pengolahan metode domonstrasi , observasi aktivitas siswa dan guru angket motivasi siswa dan tes praktek.

\section{Teknik Analisa Data}

Teknik analisis yang digunakan dalam penelitian ini adalah (1) Rata-rata nilai tes praktik dapat dirumuskan dengan nilai rata-rata $=$ jumlah semua nilai /jumlah siswa. (2) ketuntasan belajar dapat dirumuskan dengan jumlah siswa yang tuntas/jumlah siswa x 100\%. (3) lembar observasi meliputi lembar observasi aktivitas guru dan motivasi siswa.

\section{HASIL PENELITIAN}

\section{Aktivitas guru}

Hasil supervisi pendampingan pelaksanaan pembelajaran di kelas V SDN Sampangagung 1 Kutorejo Kabupaten Mojokerto menunjukkan belum optimalnya dalam penyusunan rencana pelaksanaan pembelajaran maupun pelaksanaan pembelajaran. Adapun hasil supervisi rencana pembelajaran dan pelaksanaan pembelajaran dapat dapat peneliti sajikan pada tabel 2 berikut ini: 
Tabel 2 Hasil Observasi Menyusun, Melaksanakan Pembelajaran (F.RPP.1, F.PBM.1)

\begin{tabular}{|c|c|c|c|c|}
\hline \multirow{2}{*}{ No } & Nama Kegiatan & \multicolumn{3}{|c|}{ Nilai } \\
\cline { 3 - 5 } & & Pra Siklus & Siklus I & Siklus II \\
\hline 1 & Menyusun Pembelajaran (RPP) & 2.25 & 3,45 & 4,13 \\
2 & Melaksanakan Pembelajaran & 2.54 & 3,41 & 4,04 \\
& Rata-rata & $\mathbf{2 . 3 9}$ & $\mathbf{3 , 4 3}$ & $\mathbf{4 , 0 9}$ \\
\hline
\end{tabular}

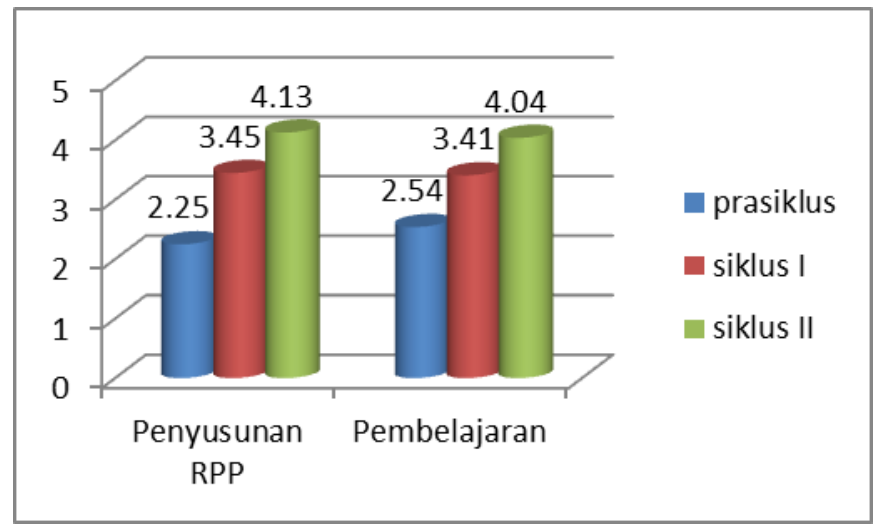

Gambar 1. Perbandingan aktivitas guru

Dari hasil belajar dapat dipaparkan sebagai berikut: (1) Analisis data ranah kognitif, (a) Terjadi kenaikan rata nilai hasil tes/ uji kompetensi teknik kebugaran dari siklus I sebesar 79 menjadi 81 pada siklus II, (b) Prosentase ketuntasan mencapai $100 \%$, pada siklus I maupun Siklus II, (c) Dari analisis data diambil kesimpulan bahwa guru, maupun siswa dalam proses pembelajaran mengalami kenaikan yang signifikan dalam ranah kognitif.

Analisis Data Pembanding Ranah Psikomotor, (1) Rata-rata ranah psikomotor mengalami kenaikan yang signifikan yakni dari 71 pada siklus I menjadi 75 pada siklus II, (2) Prosentasi ketuntasan ranah psikomotor mengalami kenaikan dari 83.3 menjadi 91.7 pada siklus II, (3) Rata-rata hasil praktik mengalami kenaikan yang signifikan yakni : 4 point (75-71), (5) Prosentase ketuntasan belajar juga mengalami kenaikan sebesar 8,4 point, yakni $(91.7-83.3)$

Analisis Data aspek afektif, (1) Rata-rata pada ranah afektif mengalami kenaikan dari 76,6 menjadi 82,5, (2) Ketuntasan belajar mengalami kenaikan dari $74,6 \%$ menjadi 91,66 \%. Analisis Data Observasi guru saat melakukan perbaikan pembelajaran, (1) Terjadi kenaikan dari siklus 1 ke siklus -2 yakni, 79 pada siklus I menjadi 86,6 pada siklus II. (2) Kenaikannya sebesar 7, 6 point (86.6 - 79). Berdasarkan data tersebut bahwa guru dalam melakukan perbaikan sudah secara maksimal.

\section{KESIMPULAN}

Berdasarkan hasil penelitian dapat disimpulkan: (1) Dari hasil analisis didapat bahwa kompetensi guru dalam melaksanakan pembelajaran dengan metode demontrasi mengalami peningkatan pada siklus I skor nilai rata-rata

10 BRILLIANT: Jurnal Riset dan Konseptual Volume 2 Nomor 1, Februari 2017 
sebesar 3,43 meningkat pada siklus II menjadi 4,09. Pada Siklus I, Rata-rata kognitif 79 dengan ketuntasan $100 \%$ mengalami peningkatan menjadi 81 dengan ketuntasan $100 \%$ pada siklus II. Rata-rata aspek psikomotor 71 , dengan ketuntasan $83.3 \%$ mengalami peningkatan menjadi 75 dengan ketuntasan 91,7\% pada siklus II. Rata-rata ranah afektif 76.6, dengan ketuntasan sebesar $74.6 \%$ mengalami peningkatan menjadi 82,5 dengan ketuntasan $91,66 \%$ pada siklus II. (3) Untuk motivasi belajar didapatkan skor nilai sebesar 85 termasuk sangat baik.

\section{SARAN}

Agar proses belajar mengajar lebih efektif dan lebih memberikan hasil yang optimal bagi siswa, maka disampaikan saran sebagai berikut: (1) Metode domonstrasi memerlukan persiapan yang cukup matang, sehingga guru harus mampu menentukan atau memilih topik yang benar-benar bisa diterapkan. (2) Guru hendaknya lebih sering melatih siswa dengan berbagai metode pengajaran, walau dalam taraf yang sederhana, dimana siswa nantinya dapat menemukan pengetahuan baru, memperoleh konsep dan keterampilan. (3) Perlu adanya penelitian yang lebih lanjut, karena hasil penelitian ini hanya dilakukan di kelas V SDN Sampangagung-1Kecamatan Kutorejo Kabupaten Mojokerto, tahun pelajaran 2016-2017.

\section{DAFTAR RUJUKAN}

Arikunto, Suharsimi , 2002. Prosedur Penelitian Suatu Pendekatan Praktik. Jakarta PT. Rineksa Cipta

Engkos, S.R. 1994. Penjaskes. Jakarta; Erlangga

Husni, Agusta, dkk. 1987. Buku pintar Olahraga . Jakarta; CV Mawar Gempita

Muhajir, 1998, Pendidikan Jasmani dan Kesehatan, Untuk SMU Kelas 2, Jakarta; Erlangga

Mulyaningsih, Farida dkk. 2011. Pendidikan Jasmani Olah Raga dan Kesehatan untuk Sekolah Dasar Kelas I - VI. Jakarta : Pusat Perbukuan.

Slamet, S.R. 1994. Penjaskes 3. Jakarta; Tiga Serangkai

Suharno. 1986, Ilmu Kepelatihan Olah Raga Yogyakarta; IKIP Yogyakarta.

Syarifuddin, Aib. 1997, Penjaskes 1,2,3, Jakarta; PT. Gramedia Widiasmara Indonesia. 